\title{
Kecakapan Pengungsi dalam Berbahasa Indonesia
}

\section{Sri Hapsari Wijayanti a,1}

${ }^{a}$ Universitas Katolik Indonesia Atma Jaya, Jakarta, Indonesia

${ }^{1}$ sri.hapsari@atmajaya.ac.id

\begin{tabular}{ll}
\hline Article info & A B S T R A C T \\
\hline Article history: & The problem of refugees is not just an international problem, but also a \\
Revised : 10-03-2020 & national problem. Especially temporary countries, such as Indonesia. \\
Accepted: 13-05-2020 & One of the main needs of refugees is being able to communicate with \\
& local people. However, due to language barriers, they often cannot \\
& communicate verbally with residents, even miscommunication occurs. \\
& This study aims to describe the Indonesian conditions pre-course \\
& learning, find out BIPA learning outcomes for refugees, and evaluate \\
& post-course learning. The respondents were 34 people who have been \\
& lived in more than two years in Indonesia. This study used a descriptive \\
& qualitative and quantitative approach. Data collection techniques are \\
& carried out through online questionnaires ( $g$-form), direct observation, \\
& and interviews. The results of this study indicate that 100\% of refugees \\
& cannot speak Indonesian when the first time arrived in Indonesia. They \\
& rely on English and non-verbal language skills. After taking of basic \\
& BIPA course, the tests show that the average refugees have good spoken \\
and written Indonesian competency and can be further improved & because they have higher learning motivation.
\end{tabular}

Keywords:

$B I P A$,

Indonesian,

inter-culture communication, refugees

\begin{abstract}
Masalah pengungsi bukan masalah internasional saja, melainkan juga masalah nasional. Khususnya negara tempat tinggal sementara, seperti Indonesia. Salah satu kebutuhan utama pengungsi adalah berkomunikasi dengan masyarakat lokal. Namun, karena kendala bahasa, sering kali mereka tidak dapat berkomunikasi secara verbal dengan warga lokal, bahkan terjadi miskomunikasi. Tujuan penelitian ini adalah mendeskripsikan kondisi berbahasa Indonesia pengungsi prakursus BIPA, mengetahui hasil belajar BIPA bagi pengungsi, serta mengevaluasi pembelajaran pascakursus BIPA. Responden penelitian ini adalah 34 pengungsi yang telah tinggal lebih dari dua tahun di Indonesia. Penelitian ini menggunakan pendekatan deskriptif kualitatif dan kuantitatif. Teknik pengumpulan data dilakukan melalui kuesioner secara daring ( $g$-form), observasi langsung, dan wawancara. Hasil penelitian ini menunjukkan bahwa $100 \%$ pengungsi tidak dapat berbicara dalam bahasa Indonesia saat kali pertama datang di Indonesia. Mereka mengandalkan kemampuan berbahasa Inggris dan berbahasa nonverbal. Setelah mengikuti kursus BIPA dasar, hasil tes memperlihatkan rata-rata pengungsi memiliki kompetensi bahasa Indonesia lisan dan tertulis yang tergolong baik dan dapat lebih ditingkatkan mengingat motivasi belajar mereka cukup tinggi.
\end{abstract}

Copyright $@ 2020$ Institut Agama Islam Negeri Syekh Nurjati Cirebon. All rights reserved.

\section{PENDAHULUAN}

Masalah pengungsi (refugees) asal Timur Tengah sudah menjadi masalah nasional dan internasional, artinya masalah pengungsi merupakan tanggung jawab negara yang ditempati dan menjadi masalah internasional karena berkaitan dengan kerja sama antarnegara (Krustiyati, 2012). Pengungsi Timur Tengah dapat terbebas dari ketidakamanan dan ketidaknyamanan tinggal di negaranya, tetapi kemudian harus menyesuaikan diri di negara tempat tinggal sementaranya. 
Ketidakmampuan pengungsi berbahasa lokal merupakan salah satu masalah utama yang dihadapi pengungsi (Beiser \& Hou, 2001). Pengungsi yang tidak menguasai bahasa lokal berpotensi konflik dalam berinteraksi dengan orang lain. Hal itu dapat mencetuskan stres atau depresi, seperti penelitian sebelumnya yang mengungkap ketidakmampuan berbahasa lokal menyebabkan pengangguran yang berpengaruh pada kesehatan mental pengungsi (Beiser \& Hou, 2001).

Pertemuan dua budaya yang berbeda, seperti pengungsi dan warga Indonesia, menuntut penyesuaian antara satu budaya dan budaya lainnya. Komunikasi antarbudaya dapat berjalan efektif apabila para partisipan memberikan makna yang sama atas pesan yang dipertukarkan (Liliweri, 2002). Hal itu tidak bermasalah apabila pengungsi menggunakan bahasa asal mereka kepada sesama. Kenyataannya, tidak semua pengungsi mampu berbahasa Inggris sebagai bahasa internasional dan tidak semua masyarakat lokal di Indonesia menguasai bahasa Inggris. Dari penelitian sebelumnya diketahui bahwa pengungsi asal Afghanistan yang tinggal di Pekanbaru mendapat pengalaman baik dan buruk ketika berkomunikasi dengan sesama pengungsi dan masyarakat lokal. Mereka merasakan diri mereka diterima di tengah masyarakat, mendapatkan motivasi dan pembelajaran hidup, tetapi juga mengalami miskomunikasi, diskriminasi, atau pelecehan verbal dan nonverbal (Yadani S. \& Wirman, 2017).

Untuk mengatasi ketidakmampuan berkomunikasi verbal, komunikasi nonverbal dapat menggantikan serta mendukung komunikasi verbal (Lestari et al., 2015; Syahrin \& Artono, 2018). Penggunaan bahasa nonverbal pun dapat memicu miskomunikasi dalam komunikasi antarbudaya, tetapi dengan adanya sikap menghargai dan menerima perbedaan budaya, seperti antara pengungsi Iran dan masyarakat Makassar, hal itu teratasi sehingga komunikasi dapat berjalan efektif (Umar, 2018).

Terjadinya benturan pengungsi dengan masyarakat lokal bukan semata-mata masalah bahasa, melainkan juga budaya. Pengungsi membawa budaya asal negaranya dan belum mengetahui atau belum dapat menyesuaikan diri dengan budaya Indonesia. Kondisi seperti itu tentu menimbulkan ketidaknyamanan dalam kehidupan bersama. Sebagai pendatang, pengungsi perlu menyesuaikan diri dengan kondisi masyarakat Indonesia. Untuk dapat menyesuaikan diri, pengungsi membutuhkan keterampilan berkomunikasi sehari-hari dalam bahasa Indonesia serta mengenal adat istiadat dan budaya Indonesia. Dengan memahami bahasa dan budaya Indonesia, pengungsi dapat diakui dan menyatu dengan masyarakat setempat.

Bahasa Indonesia bagi penutur asing (BIPA) mengarahkan pemelajar "terampil berbahasa Indonesia untuk berbagai tujuan dalam berbagai konteks sesuai dengan kompetensi masing-masing level" (Kurniawan, P, Batubara, Herlina, \& Larasati, 2019); "mampu berbahasa Indonesia sesuai dengan situasi dan kondisi" (Ningrum, Waluyo, \& Winarni, 2017); dan menguasai aspek linguistik yang terintegrasi dengan budaya Indonesia (Saddhono, 2015). Kebutuhan belajar bahasa semata-mata agar pemelajar bahasa kedua dapat "bertahan hidup di budaya lain" sehingga mereka diharapkan mempunyai kompetensi komunikatif (Muliastuti, 2017). Dalam hal ini, faktor lingkungan nonformal efektif dalam proses pemelajaran bahasa kedua karena telah memberikan ruang, tempat, dan waktu tidak terbatas (Zahidin \& Mulyaningsih, 2016). 
Pemelajar akan mendapat pengalaman yang nyata ketika berada di tengah masyarakat dengan aneka ragam bahasa. Hal tersebut sejalan dengan tujuan pengajaran BIPA: (a) berkomunikasi praktis sehari-hari dengan penutur bahasa Indonesia dan (b) menggali kebudayaan Indonesia dengan segala aspeknya (Soewandi dalam Suyitno, 2017). Aspek bahasa dan aspek budaya tidak dapat dipisahkan dalam pembelajaran bahasa Indonesia. Keduanya dibutuhkan pengungsi karena pengungsi akan tinggal di Indonesia dalam waktu tidak pasti dan hampir setiap hari mau tidak mau berinteraksi dan berkomunikasi dengan orang Indonesia. Karena itu, penting diselenggarakan kursus BIPA guna membantu mereka sintas (survive) di Indonesia.

Penelitian dengan target pengungsi pernah dilakukan dari segi komunikasi antarbudaya (Lestari et al., 2015) serta pengaruh pengangguran dan kesehatan metal pengungsi terhadap pemerolehan bahasa kedua (Beiser \& Hou, 2001). Berbeda dengan penelitian sebelumnya yang menggunakan responden dari satu negara asal pengungsi, dalam penelitian ini responden pengungsi berasal dari tiga negara di Timur Tengah, yaitu Afghanistan, Somalia, dan Ethiopia. Tujuan penelitian ini adalah (1) mendeskripsikan kondisi berbahasa Indonesia sebelum belajar (prakursus) BIPA; (2) mengetahui hasil belajar BIPA; mengevaluasi pembelajaran setelah kursus (pascakursus) BIPA.

\section{METODE}

Penelitian ini merupakan penelitian deskriptif kuantitatif dan kualitatif. Penelitian ini menggunakan data yang dikuantifikasikan dari hasil tes dan kuesioner yang selanjutnya dianalisis secara deskriptif (Sugiyono, 2013). Penelitian ini dilakukan dalam kondisi alamiah untuk mengumpulkan data secara langsung dari target penelitian (Sugiyono, 2013).

Waktu penelitian berlangsung selama masa kursus tingkat dasar, yaitu empat bulan (September sampai dengan Desember 2019). Kursus diadakan seminggu satu kali, selama dua jam, empat belas kali pertemuan. Materi yang diberikan adalah bahasa Indonesia formal dan nonformal, yang mencakup keterampilan berbicara, menulis, menyimak, dan membaca. Keempat keterampilan tersebut terintegrasi dalam tema-tema yang berbeda pada setiap pertemuan. Dengan kata lain, satu tema mengikat setiap materi keterampilan berbahasa, termasuk memberikan tambahan informasi budaya yang relevan (Muliastuti, 2017). Setiap dua bulan dilakukan evaluasi untuk mengetahui kemampuan responden.

Untuk mencapai tujuan penelitian pertama dan ketiga, pengambilan data dilakukan setelah kursus berakhir pada Desember 2019. Penulis mengirimkan kuesioner melalui g-form dan melakukan wawancara. Kuesioner terdiri atas kondisi penguasaan bahasa Indonesia saat pertama kali datang di Indonesia dan hasil belajar bahasa Indonesia pengungsi sebelum dan setelah mengikuti kursus BIPA. Responden yang mengisi kuesioner berjumlah 34 orang, mayoritas lakilaki $(88 \%)$. Responden yang diwawancarai berjumlah empat orang. Wawancara dilakukan untuk melengkapi kuesioner dengan mengeksplorasi lebih dalam cara responden menyesuaikan diri di masyarakat, cara mereka belajar bahasa Indonesia sebelum mengikuti kursus, motivasi belajar, serta pendapat responden setelah mengikuti kursus.

Di samping mengumpulkan data melalui pengisian kuesioner dan wawancara, juga dilakukan observasi terhadap aktivitas berbahasa responden di 
dalam kelas dan di luar kelas. Interaksi berbahasa yang digunakan kepada sesama responden, dengan penulis, atau dengan masyarakat diamati dan dicatat di lembar pengamatan. Catatan dan amatan lapangan tersebut akan digunakan dalam analisis.

Teknik pengumpulan data untuk mencapai tujuan penelitian kedua adalah tes tengah kursus (mid assignment) pada Oktober 2019 dan akhir kursus (final assignment) pada Desember 2019. Tes berbentuk tertulis dan lisan. Tes tertulis merupakan tes integratif, mencakup menyimak, tata bahasa, dan menulis. Bentuk tes berupa menjawab pertanyaan dari audio dan bacaan, pilihan ganda, mengisi kalimat yang rumpang, menulis satu hingga dua kalimat sesuai dengan gambar, dan menulis sebuah paragraf deskriptif. Adapun kemampuan berbahasa lisan diuji melalui tes berbicara secara berpasangan dan perseorangan.

Pada tengah kursus, responden diberikan konteks percakapan yang berbeda-beda. Selama lima menit, responden berperan sesuai dengan tema. Konteks dan tema percakapan berkisar situasi sosial yang nyata, seperti: berkenalan di suatu tempat, meminta tolong, memerintah, menginformasikan, dan mengungkapkan perasaan (Jazeri, 2016). Situasi percakapan adalah ruang publik, seperti: pusat belanja, bandara, dan restoran (foodcourt). Pada akhir kursus, tes lisan diberikan dalam bentuk berpidato. Masing-masing peserta menceritakan pengalaman berada di Indonesia selama maksimal sepuluh menit. Di dalam penilaian tes berbicara digunakan rubrik kualitatif dan kuantitatif. Rubrik kualitatif berupa deskripsi penilaian atau catatan tentang masing-masing responden, sedangkan kuantitatif berupa penilaian berbentuk skor. Penilaian berbicara diadopsi dari Valette dalam Riny (2013) yang meliputi lafal dan intonasi, kosakata, tata bahasa, dan cara penyampaian ide, termasuk bahasa tubuh.

Dalam analisis, data kualitatif yang berasal dari hasil wawancara ditranskripsi secara verbatim. Tahapan analisis kualititatif merujuk pada Miles dan Huberman (dalam Sugiyono, 2013), yaitu mereduksi data, mengategorisasi atau mengelompokkan data, menyajikan data hasil reduksi agar terorganisasi, dan menarik simpulan atau memverifikasi. Data kuantitatif hasil kuesioner ditampilkan dalam grafik persentase, sedangkan data dari tes dihitung dari selisih antara nilai akhir kursus dan nilai tengah kursus yang kemudian ditampilkan dalam grafik, lalu dideskripsikan, diinterpretasikan, dan disimpulkan.

\section{HASIL DAN PEMBAHASAN}

Data demografi memperlihatkan bahwa responden berasal dari Afghanistan (76\%), diikuti Somalia (15\%) dan Ethiopia (9\%). Usia mayoritas responden ratarata 20--30 tahun (94\%) (Gambar 1). Diamati dari segi usia, responden berada dalam rentang usia produktif yang sudah mandiri, mapan, dan mampu berkarya. 


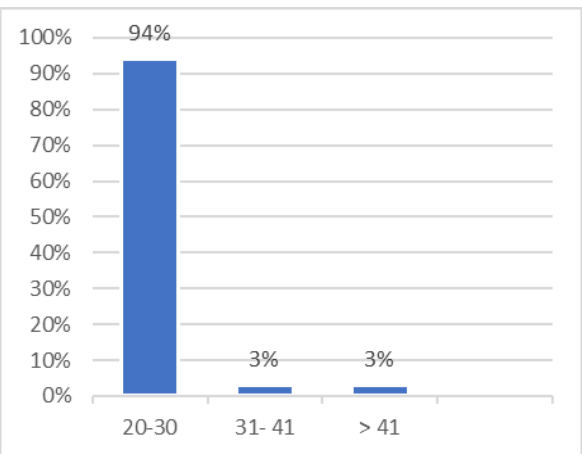

Gambar 1. Usia Responden

Responden penelitian ini sudah menetap di Indonesia selama 5-7 tahun (61\%), sisanya 2-4 tahun (39\%) (Gambar 2). Dilihat dari lama mereka tinggal, dipastikan pemelajar sudah mampu berbicara dalam bahasa Indonesia. Hal itu benar adanya. Terbukti beberapa dari mereka dengan luwesnya berbicara bahasa Indonesia meskipun masih ditemukan ketidaktepatan urutan kata dan percampuran bahasa Indonesia dengan bahasa Inggris. Beberapa dari pemelajar bahkan sudah mencampurkan bahasa Indonesia dengan bahasa Jawa, Sunda, atau Betawi. Akan tetapi, diakui bahwa mereka belum pernah mendapat kesempatan belajar dalam situasi formal seperti kursus BIPA dan belum pernah belajar bahasa Indonesia formal.

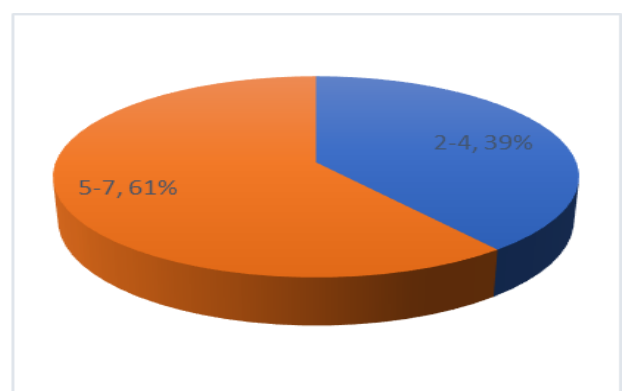

\section{Gambar 2. Lama Tinggal Responden ( dalam tahun)}

\section{Kondisi Berbahasa Prakursus}

Ketika kali pertama datang ke Indonesia, 50\% pemelajar mengaku takut dan 26\% merasa senang (Gambar 3). Perasaan tersebut lazim dirasakan sebagai pengungsi atau orang asing yang akan menetap sementara di negara lain. Pemelajar merasa senang karena dapat keluar dari situasi di negaranya yang tidak aman, tetapi ada rasa takut tidak dapat diterima, takut diasingkan, dan tidak dapat menyesuaikan diri dengan masyarakat Indonesia.

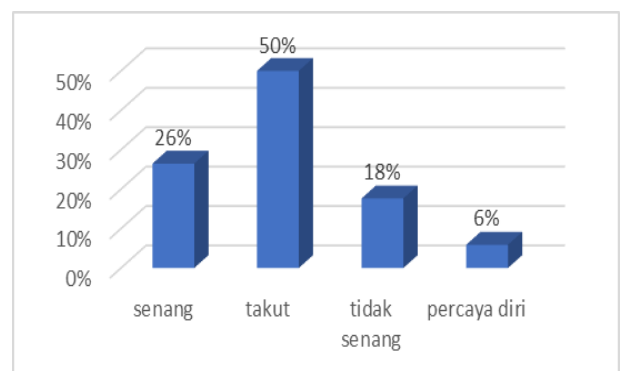

Gambar 3. Perasaan Kali Pertama Datang ke Indonesia 
Perasaan tidak nyaman dapat timbul akibat tidak ada orang yang dikenal dan ketidakmampuannya berinteraksi dengan masyarakat lokal. Sebanyak 100\% responden mengaku tidak bisa sama sekali berbahasa Indonesia ketika menginjakkan kakinya di Indonesia (Gambar 4). Meskipun demikian, pemelajar mengakui orang Indonesia menerima kekurangan tersebut; orang Indonesia dinilai ramah, baik, dan mau membantu, seperti diungkap salah satu responden: "Pertama datang, gimana, gak bisa bahasa Indonesia, tetapi orang Indonesia baik dan mau bantu" (A, laki-laki).

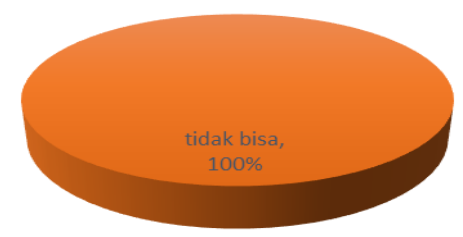

\section{Gambar 4. Kemampuan Awal Bahasa Indonesia}

Selama menetap bertahun-tahun di Indonesia, pengungsi belajar bahasa Indonesia secara mandiri dari lingkungan nonformal di tempat pemelajar tinggal yang menyebar di wilayah Jakarta, Bogor, Bekasi, Cibubur, dan Serpong. Pada saat itu yang diketahui adalah bahasa Indonesia adalah bahasa nonformal. Pemelajar sudah terbiasa menghilangkan prefiks $m e N$, ber-, menggunakan sufiks in, tidak menggunakan $-k a n /-i$ dalam percakapan. Selain itu, salah satu responden, bahkan bercerita tentang pengalaman dimarahi orang yang tampak usianya lebih tua. Ini terjadi karena lawan bicara disapa dengan sebutan kamu. Pemelajar tidak merasa bersalah, tetapi lawan bicara menunjukkan sikap tidak senang tanpa menjelaskan yang sebenarnya. Kesalahan pengungsi menggunakan kata sapaan juga juga ketika awal mengajar. Beberapa pemelajar menyapa penulis dengan kamu, di samping sebutan guru.

Untuk berkomunikasi dengan masyarakat lokal, pemelajar mengakui mengalami kesulitan (65\%), tetapi ada juga yang merasakan sedikit kesulitan (26\%) dan tidak sama sekali kesulitan (9\%) (Gambar 5). Peserta kursus yang sedikit atau tidak sama sekali mengalami kesulitan dalam berkomunikasi karena lawan bicara mampu berbahasa Inggris.

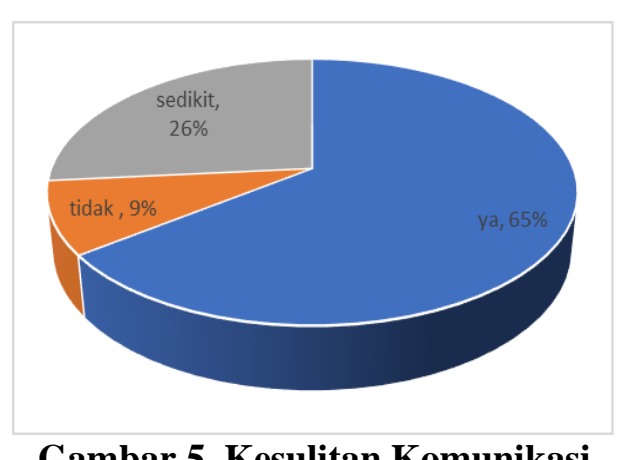

\section{Gambar 5. Kesulitan Komunikasi}

Keterampilan bahasa yang pertama kali dipelajari pengungsi adalah berbicara. Responden merasa harus bisa berbahasa Indonesia praktis karena 
menyadari kebanyakan orang Indonesia tidak mampu berbahasa Inggris, seperti diungkap pemelajar berikut: "Bagaimana, ya, orang Indonesia tidak banyak yang bisa bahasa Inggris, mau tidak mau saya harus bisa bahasa Indonesia" ( $\mathrm{S}$, perempuan).

Para pemelajar menyadari kehidupan harus terus berjalan dan berada di tengah masyarakat Indonesia merupakan cara yang membuat hidup menjadi tidak terasing dan bermakna. Selama ini, pemelajar belajar bahasa Indonesia nonformal dari lingkungan tempat tinggal, di pasar, di jalan, di stasiun, di bandara, atau di tempat-tempat umum lainnya. Di samping itu, pemelajar mencari bantuan melalui google translate, seperti pernyataan berikut. "Karena perlu makan, pergi ke pasar. Di sana sedikit-sedikit belajar bahasa, ada (memakai-penulis) google translate" (B, laki-laki).

Interaksi yang intens dengan masyarakat sekitar menyebabkan pengungsi bukan saja mampu dan mengerti bahasa Indonesia, melainkan juga mampu menggunakan bahasa daerah, seperti bahasa Jakarta, Sunda, dan Jawa. Akibatnya, dalam berbahasa Indonesia, terjadi campur kode bahasa Indonesia nonformal dengan bahasa daerah, seperti pernyataan pemelajar ketika field trip: "Panas banget di sini, Bu" (M, laki-laki); "Mau ngapain kita ke sana?" (B, laki-laki).

Di samping bahasa verbal, bahasa tubuh, seperti gerakan tangan, badan, dan wajah, merupakan bentuk komunikasi yang efektif untuk mengatasi ketidakmampuan berkomunikasi verbal dalam dua budaya yang berbeda (Lestari et al. 2015). Pengungsi menggunakan bahasa tubuh secara terpisah atau bersamaan dengan bahasa verbal. Misalnya, memegang perut diikuti dengan mimik wajah kesakitan untuk memperlihatkan sedang sakit perut dan meminta izin pulang cepat. Juga pemelajar mengatakan, "Sebentar, Ibu" sambil mengarahkan tangan kanannya ke arah mulut untuk menunjukkan akan makan siang dahulu.

Sebanyak 50\% responden belajar bahasa Indonesia untuk tujuan bercakapcakap dengan orang Indonesia, 32\% ingin mendapatkan banyak teman, dan $18 \%$ untuk tujuan bisnis (Gambar 6).

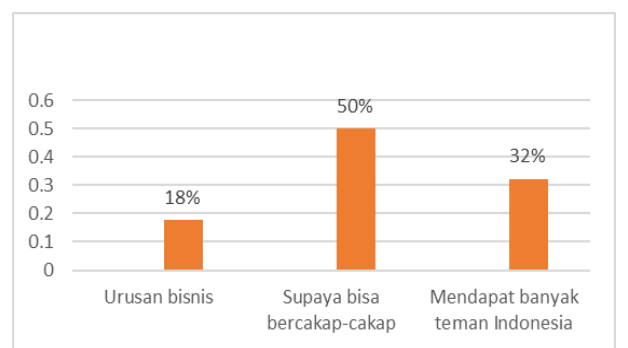

\section{Gambar 6. Tujuan Belajar Bahasa Indonesia}

Dari Gambar 6, tampak bahwa terampil berkomunikasi lisan merupakan tujuan utama pengungsi belajar bahasa Indonesia. Tujuan praktis ini berguna untuk mempertahankan hidup pengungsi karena sebagai makhluk sosial, pengungsi pastinya akan melakukan banyak kegiatan sehari-hari yang berhubungan dengan orang lain. Dengan kemampuan berbicara bahasa Indonesia, pemelajar dapat berinteraksi dengan masyarakat setempat dan menambah banyak relasi untuk menjadi rekan dalam berkomunikasi dan sumber informasi. 


\section{Hasil Belajar}

Hasil belajar bahasa Indonesia tertulis dapat diamati dari selisih nilai akhir kursus dan tengah kursus cukup bervariasi. Terdapat kemampuan pengungsi yang mengalami peningkatan, tidak berubah, atau penurunan. Grafik 7 memperlihatkan bahwa $27 \%$ pemelajar mengalami penurunan hasil belajar, yang ditunjukkan dengan selisih nilai akhir kursus dan tengah kursus sebesar (-15) sampai dengan (1) poin. Sebanyak $6 \%$ pemelajar menunjukkan nilai yang stabil, tidak ada peningkatan atau penurunan. Pemelajar yang mengalami peningkatkan nilai di akhir kursus sebesar 1--15 poin sebanyak 32\% dan 16--30 poin sebanyak $35 \%$. Hasil tersebut mengimplikasikan bahwa lebih dari separuh, tepatnya $67 \%$ pemelajar mengalami peningkatan hasil belajar, khususnya dalam tes tertulis, yang meliputi kemampuan menyimak, tata bahasa, dan menulis. Adanya peningkatan tersebut menunjukkan kompetensi responden dalam belajar bahasa Indonesia tulis tergolong baik. Diamati dari rerata nilai tengah kursus dan akhir kursus, $56 \%$ pemelajar mendapat skor B dan $32 \%$ pemelajar mendapat skor C (Gambar 8).

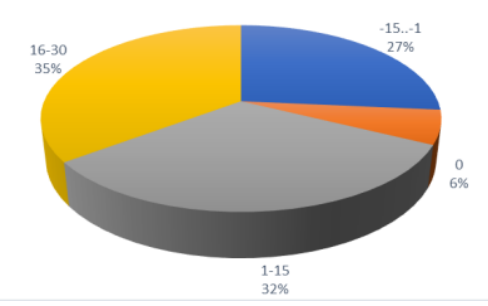

Gambar 7. Selisih Nilai Akhir dan Tengah Kursus

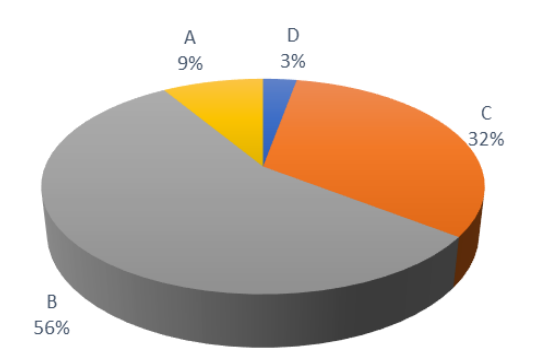

Gambar 8. Skor Rerata Nilai Responden

Penelitian ini menemukan bahwa pemelajar memperlihatkan kekurangan dalam menjawab pertanyaan dari percakapan yang diperdengarkan melalui audio. Percakapan dalam audio hanya diperdengarkan dua kali, sehingga responden harus benar-benar berkonsentrasi untuk mendengarkan percakapan yang terjadi, seperti: di mana, kapan terjadi percakapan, apa topik percakapan, siapa yang berbicara, dan apa isi giliran bicara partisipan. Penelitian ini senada dengan penelitian sebelumnya yang memperlihatkan bahwa menyimak menunjukkan hasil belajar paling rendah bagi pemelajar BIPA dari berbagi negara pada periode 2016-2017 dibandingkan kompetensi bahasa lainnya (Kurniawan, Devi, Batubara, Hernina, \& Larasati, 2019). Dalam penelitian ini, pembelajaran dalam kursus, khususnya menyimak, kurang mendapat porsi yang banyak dan kurang dilatihkan. 
Di samping menyimak, pemelajar masih memperlihatkan kekurangan dalam menulis kalimat, merangkai kalimat menjadi paragraf. Kesalahan dalam kalimat terdapat pada penempatan kata, penggunaan kata yang kurang tepat, seperti Dia berasal dari Somalia saya sedangkan Pakistan, juga ketidaktepatan penggunaan dan penghilangan imbuhan meN- dan ber-, penggunaan kata ganti kami dan kita. Temuan kekurangtepatan atau kesalahan dalam tes menulis ini sama dengan penelitian Adnyana \& Suryaniadi (2020) dan Inderasari \& Agustina (2017). Dalam tes menulis paragraf, pemelajar belum menuliskannya secara lengkap, hanya dalam satu hingga dua kalimat sederhana. Di samping itu, pemelajar belum memanfaatkan kata penghubung sebagai perangkai antarkalimat.

Adapun hasil tes lisan memperlihatkan rata-rata skor B dengan rentang nilai 70-80 (Gambar 9). Skor tersebut menunjukkan mayoritas pemelajar memiliki kemampuan berbahasa Indonesia lisan yang tergolong baik. Dalam tes percakapan, pemelajar cenderung menggunakan bahasa Indonesia nonformal. Partisipan percakapan yang belum tentu saling mengenal, sudah dapat membuka dan mengakhiri percakapan serta mengembangkan topik percakapan dengan baik. Namun, masih ditemukan kesulitan memilih kata-kata untuk diucapkan sehingga untuk menggantikan kata-kata yang tidak ditemukannya itu, pemelajar menggunakan kosakata negaranya atau dari bahasa Inggris. Adanya kendala menemukan kata-kata dalam giliran berbicara, pemelajar rerata melakukan percakapan tidak lebih dari sepuluh menit seperti waktu yang dialokasikan.

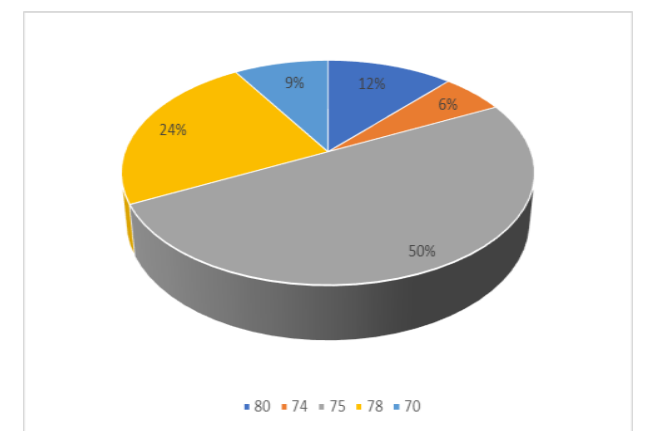

\section{Gambar 9. Rata-rata nilai bahasa lisan}

Pemelajar yang hasil tesnya tergolong baik dalam tes lisan dan tertulis dapat dikonfirmasi sebagai berikut. Pertama, sudah lama tinggal di Indonesia dan sering berinteraksi dengan masyarakat lokal, sehingga untuk percakapan menggunakan bahasa nonformal bukan hambatan meskipun diamati masih ditemukan kesulitan dalam menemukan kata-kata yang tepat. Selain ragam nonformal, dalam tes tertulis juga diuji kemampuan berbahasa formal. Hasilnya, masih ditemukan penggunaan ragam tulis nonformal, seperti menghilangkan prefiks meN- dan ber-, sufiks -kan dan - $i$ dalam menulis, ketiadaan unsur bahasa (subjek, predikat, atau objek) dalam kalimat.

Kedua, pemelajar berusia muda memiliki motivasi belajar lebih tinggi. Hal itu terbukti dari keaktifan bertanya, meminta klarifikasi, dan berkomentar ketika proses belajar di kelas, setelah kelas berakhir, ketika berdiskusi dalam grup whatsapp, atau dalam berkomunikasi dengan mahasiswa Indonesia. Meskipun pemelajar berasal dari negara yang berbeda-beda dan belum semua saling mengenal, tetapi dapat cepat bersosialisasi sehingga suasana belajar cukup kondusif. Dalam diskusi, pemelajar yang sudah lancar berbahasa Indonesia ikut 
membantu memperjelas materi kepada teman-teman yang kurang memahami dengan menggunakan bahasa asal pemelajar (bahasa Persia, bahasa Arab, atau bahasa Somalia). Motivasi eksternal dan motivasi internal tersebut telah mendorong proses belajar bahasa kedua semakin cepat dan efektif (Zahidin \& Mulyaningsih, 2016). Motivasi belajar BIPA yang tinggi terbukti dari hasil belajar yang berkategori baik dalam penelitian ini.

\section{Evaluasi Pembelajaran Pascakursus}

Peserta kursus belajar secara otodidak, yakni langsung berinteraksi dengan warga setempat sejak dua hingga tujuh tahun yang lalu. Ketika ditanyakan apakah mengalami kesulitan belajar secara formal di kelas selama kursus, dijawab tidak (65\%), tetapi masih ada yang mengatakan kesulitan (26\%) dan agak kesulitan (9\%). Hal ini dapat dilihat pada Gambar 10. Jawaban tidak kesulitan oleh 65\% pemelajar didasari atas pengalaman tinggal bertahun-tahun di Indonesia sehingga membuat lebih percaya diri dalam berkomunikasi dan dapat menyerap pelajaran di tempat kursus dengan baik. Hal ini karena selama belajar menggunakan bahasa pengantar berupa bahasa Indonesia. Kesulitan dan agak kesulitan dialami oleh pemelajar yang tidak hadir secara rutin, kurang dapat mengikuti perkembangan materi yang diberikan, dan kurang berinteraksi dengan sesama peserta di kelas.

Kendati demikian, sebanyak $82 \%$ mengakui senang belajar bahasa Indonesia (Gambar 11) dan 91\% mengatakan jauh lebih pintar setelah mengikuti kursus (Gambar 12). Salah satu pemelajar bahkan mengatakan beruntung dapat mengikuti kursus karena mendapat ilmu tentang ragam formal: "Sebelum aku ikut aku cuma bisa ngobrol biasa maksudnya aku gak tahu tentang formal bahasa tapi sekarang aku sudah tahu dan aku bisa tulis dan bicara lebih baik dari dulu“ (S, perempuan).

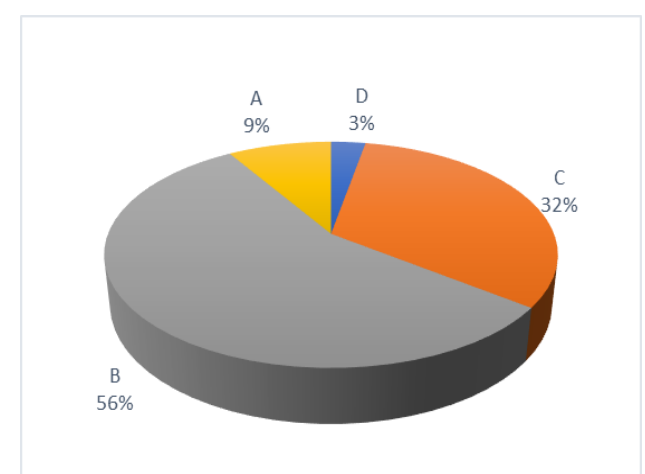

Gambar 12. Tingkat Kesulitan Belajar

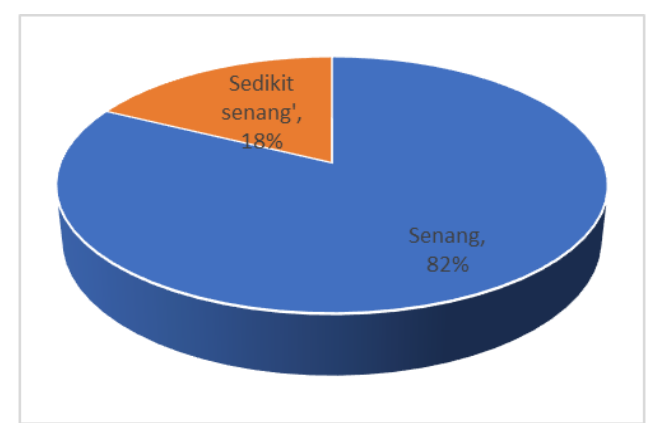

Gambar 13. Pendapat Belajar Bahasa Indonesia 


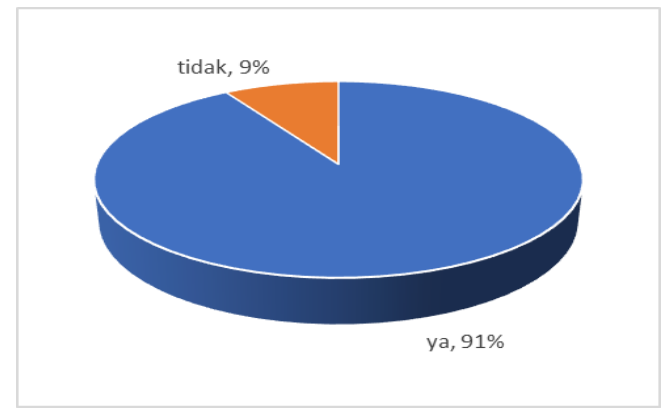

Gambar 14. Pernyataan Lebih Pintar Setelah Kursus

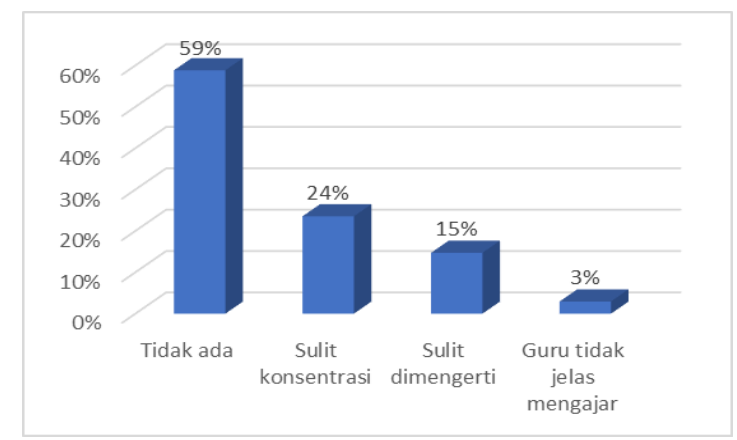

Gambar 15. Jenis Kesulitan Belajar

Pembelajaran di kelas menerapkan metode tutorial, diskusi, tubian latihan di kelas, di luar kelas, dan field trip. Adapun tekniknya dengan mengulang kembali materi yang diberikan pada pertemuan seminggu sebelumnya. Saat pembelajaran di luar kelas, pemelajar didampingi oleh asisten untuk berinteraksi dengan masyarakat. Pembelajaran dengan metode field trip bertujuan menciptakan suasana belajar yang berbeda, menciptakan pembelajaran yang menyenangkan dan tidak membosankan, sekaligus membangun kepercayaan diri dan komunikasi pada lingkungan sosial yang nyata (Ardiansyah, 2020).

Field trip dalam kursus ini sekaligus memperkenalkan budaya Indonesia, seperti: destinasi sejarah, wisata kuliner, dan kehidupan masyarakat kebanyakan, dari kalangan menengah bawah, di Jakarta. Di samping mempererat hubungan antarpengungsi, metode ini digunakan untuk memperlancar kemampuan berbicara dengan warga Indonesia di sekitar Kota Tua, dan ruang-ruang publik lainnya, seperti Pasar Modern BSD dan Rusunawa Muara Baru, Pluit. Para pemelajar dikondisikan seperti warga Jakarta umumnya, yaitu menuju lokasi pulang pergi naik transjakarta atau grab yang dipesan secara daring. Di Kota Tua dan Rusunawa Muara Baru, pemelajar secara berkelompok mewawancarai narasumber setempat dengan pertanyaan yang sudah disiapkan. Di Pasar Modern BSD, pemelajar melakukan transaksi jual-beli dengan membeli makanan atau minuman khas yang sudah ditentukan dan mencoba menawar jika memungkinkan. Semua kegiatan lapangan itu dilaporkan secara lisan atau tertulis dan didiskusikan di kelas.

Dalam hal metode belajar BIPA yang diterapkan, pembelajar tidak mempermasalahkan, baik metode diskusi atau metode apa pun disukai (Gambar 16). Di kelas, penulis menjelaskan materi pokok dalam bentuk tutorial lebih dahulu, diikuti dengan model atau contoh, dan diakhiri dengan praktik atau latihan di dalam kelas atau di luar kelas pada hari yang sama atau berbeda. Sesekali diselingi dengan bernyanyi bersama dari tayangan lagu di YouTube untuk 
mendukung materi. Pembelajaran yang interaktif, komunikatif, menyenangkan, dan berbasis teknologi merupakan metode pembelajaran yang telah diterapkan di kelas. Keberagaman metode pembelajaran bertujuan agar tujuan pembelajaran tercapai dan suasana belajar menyenangkan.

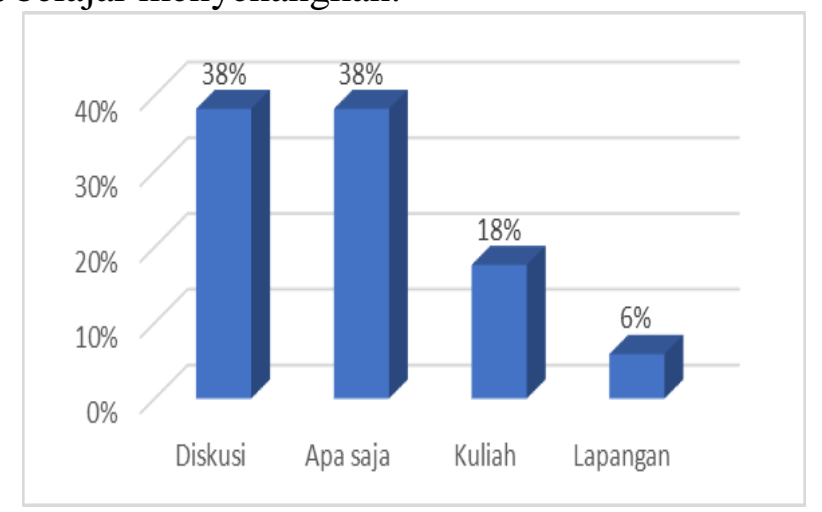

Gambar 16. Metode Belajar yang Disukai

Hal menarik tampak pada Gambar 16, metode lapangan (field trip) kurang disukai $6 \%$ pemelajar. Meskipun jumlah tersebut tergolong kecil, hal itu menandakan bahwa pembelajar lebih senang belajar di dalam kelas daripada di luar kelas. Hasil pengamatan menunjukkan bahwa belajar di luar kelas tidak diikuti oleh semua peserta belajar. Hal itu disebabkan jadwal field trip dilakukan lebih awal dari waktu belajar atau pada hari yang berbeda. Jadwal tersebut mengakibatkan beberapa pemelajar tidak dapat ikut. Meskipun demikian, ditemukan ada pemelajar yang tidak suka jalan-jalan. Hal itu terbukti dari ungkapan spontan ketika berada di kelas: "Saya enggak suka jalan-jalan, mau belajar di kelas (tersenyum)" (S, laki-laki). Selain itu, pemelajar tidak dapat mengikuti field trip karena harus bekerja atau sudah ada jadwal kursus lain.

Ketika ditanyakan apakah ingin belajar bahasa Indonesia tingkat lanjut, sebanyak 94\% pembelajar menjawab mau (Gambar 17). Hal itu didukung ucapan pembelajar saat usai acara perpisahan (Graduation Day): "Saya mau belajar bahasa Indonesia lagi kalau gratis (tertawa)" (H, laki-laki); "Kapan belajar lagi, $\mathrm{Bu}$, saya pasti rindu belajar" (S, laki-laki).

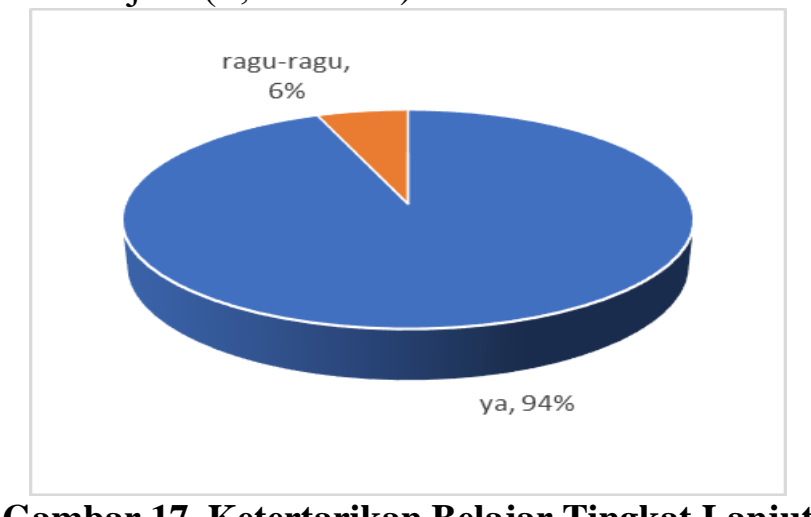

\section{Gambar 17. Ketertarikan Belajar Tingkat Lanjut}

Meskipun hanya tinggal sementara di Indonesia, 94\% pembelajar menyatakan bangga berbahasa Indonesia (Gambar 18). Dengan kemampuan berbahasa Indonesia yang dimiliki, pembelajar dapat berinteraksi dengan warga Indonesia tanpa kendala dan menambah banyak relasi atau teman. Hal ini seperti 
ungkapan berikut: "Dengan bisa bahasa, saya bisa ajak bicara orang sini" (A, lakilaki).

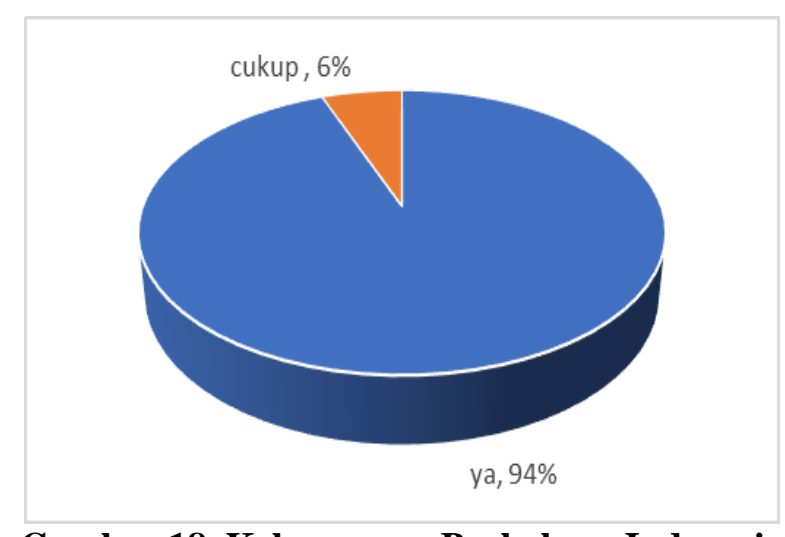

Gambar 18. Kebanggaan Berbahasa Indonesia

\section{SIMPULAN DAN SARAN}

Kemampuan berbahasa lisan nonformal merupakan kebutuhan utama yang mendesak ketika pengungsi datang ke Indonesia dalam kondisi tidak dapat sama sekali berkomunikasi dalam bahasa Indonesia. Saat penelitian diambil, pengungsi sudah mampu berbahasa lisan secara komunikatif. Setelah mengikuti kursus BIPA, hasil belajar menunjukkan kategori baik. Artinya, kompetensi berbahasa Indonesia para pemelajar sudah cukup memuaskan dan berpotensi dapat lebih ditingkatkan, baik lisan maupun tertulis. Penelitian ini tidak mengamati hasil belajar keempat kompetensi bahasa secara mendalam. Karena itu, penelitian selanjutnya dapat mengamati masing-masing kompetensi bahasa Indonesia dari pengungsi yang telah lebih dari setahun tinggal di Indonesia.

Jika mengamati motivasi belajar yang tinggi, disarankan BIPA bagi pengungsi dapat dilanjutkan ke tingkat berikutnya yang lebih tinggi karena manfaatnya cukup banyak dan dapat langsung dirasakan oleh pengungsi. Namun, sebelum kursus perlu dilakukan tes penempatan untuk mengetahui tingkat kemampuan peserta sehingga memudahkan pengajar untuk menekankan materi pembelajaran sesuai dengan kebutuhan peserta. Dengan terus-menerus belajar bahasa Indonesia, pengungsi dapat lebih percaya diri ketika berinteraksi dalam berbagai situasi formal dan tidak formal dengan masyarakat Indonesia.

\section{UCAPAN TERIMA KASIH}

Penulis mengucapkan terima kasih kepada Pusat Pemberdayaan Masyarakat Unika Atma Jaya, Jakarta, yang telah mendukung pendanaan program SILVER for Refugees tahun 2019.

\section{DAFTAR PUSTAKA}

Adnyana, I. B. A., \& Suryaniadi, S. M. (2020). Kajian kesalahan pemelajar BIPA dalam praktik menulis di Politeknik Negeri Bali. Deiksis: Jurnal Pendidikan Bahasa Dan Sastra Indonesia, 7(1), 27-35.

Ardiansyah, E. H. (2020). Mengembangkan sikap positif dan pemahaman siswa melalui pembelajaran kontekstual dengan metode demonstrasi atau field trip. PEDAGOGIA: Jurnal Pendidikan, 9(1), 81-89.

Beiser, M., \& Hou, F. (2001). Language acquisition, unemployment and depressive disorder among Southeast Asian refugees: a 10-year study. Social 
Science \& Medicine, 53, 1321-1334.

Inderasari, E., \& Agustina, T. (2017). Pembelajaran Bahasa Indonesia pada mahasiswa asing dalam program BIPA IAIN Surakarta. Pendidikan Bahasa Dan Sastra Indonesia, 6(2), 6-15.

Jazeri, M. (2016). Model perangkat pembelajaran keterampilan berbicara dengan pendekatan komunikatif kontekstual bagi mahasiswa asing. LITERA, 15(2), 217-226.

Krustiyati, A. (2012). Kebijakan penanganan pengungsi di Indonesias: Kajian dari konvensi pengungsi tahun 1951 dan protokol 1967. Law Review, XII(2), 171-192.

Kurniawan, Devi, A. P., Batubara, D. H., Hernina, \& Larasati. (2019). Pelaksanaan program BIPA dan hasil pembelajarannya. JBIPA, 1(1), 11-21.

Kurniawan, P, D. A., Batubara, D. H., Herlina, \& Larasati. (2019). Pelaksanaan program BIPA dan hasil pembelajarannya. JIPA (Jurnal Bahasa Indonesia Bagi Penutur Asing), 1(1), 11-21.

Lestari, I., Cangara, H., \& Darwis. (2015). Pengungsi dan pencari suaka Afganistan dengan masyarakat lokal di kota Makassar:(Suatu analisis efektfivitas komunikasi antar budaya). Jurnal Komunikasi KAREBA, 4(2), $101-115$.

Liliweri, A. (2002). Makna budaya dalam komunikasi antarbudaya. Yogyakarta: LKiS.

Muliastuti, L. (2017). Bahasa Indonesia bagi penutur asing. Jakarta: Yayasan Pustaka Obor Indonesia.

Ningrum, R. K., Waluyo, H. J., \& Winarni, R. (2017). BIPA (bahasa Indonesia penutur asing) sebagai upaya internasionalisasi universitas di Indonesia. The 1st Education and Language International Conference Proceedings, 726732.

Riny, T. M. (2013). Penyusunan rubrik kelas berbicara BIPA 1. Konferensi Linguistik Tahunan Atma Jaya 11, 63-67.

Saddhono, K. (2015). Integrating culuter in Indonesian language learning for foreign speakers at Indonesian universities. Journal of Language Literature, 6(2), 349-353.

Sugiyono. (2013). Metode penelitian kuantitatif kualitatif dan R\&D. Bandung: Alfabeta.

Suyitno, I. (2017). Pengembangan Bahan Ajar Bahasa Indonesia untuk Penutur Asing (BIPA) berdasarkan Hasil Analisis Kebutuhan Belajar. Wacana, 9(1), $62-78$.

Syahrin, M. A., \& Artono, H. B. (2018). Legal impacts of the existence of refugees and asylum seekers in Indonesia. International Journal of Civil Engineering and Technology (IJCIET), 9(5), 1051-1058.

Umar, N. J. (2018). Penggunaan simbol-simbol komunikasi non verbal antara pengungsi Iran dan warga lokal di Makassar. Jurnal Komunikasi KAREBA, 7(2), 295-303.

Yadani S., F., \& Wirman, W. (2017). Pengalaman komunikasi dan konspe diri pengungsi asal Afganistan di Kecamatan Rumbai. JOM FISIP, 4(2), 1-14.

Zahidin, M. A., \& Mulyaningsih, I. (2016). Teori koneksionisme dalam pembelajaran bahasa kedua anak usia dini. Journal Indonesian Language Education and Literature, 1(2), 87-100. 